\title{
Jesus the Great Teacher: Didactic Dimension Behind the Great Commission of Jesus Christ in Matthew 28:16-20
}

\author{
F. B. Arthur Gerung ${ }^{1}$, Yemdin Wonte ${ }^{2}$, Ryanto Adilang ${ }^{3}$ \\ Institut Agama Kristen Negeri Manado \\ billygerung@gmail.com ${ }^{1}$, yemdinwonte@gmail.com², ryanadilang20@gmail.com³
}

\begin{abstract}
The Great Commission is a command of Jesus that He announce to His disciples before $\mathrm{He}$ was lifted up to heaven. This Great Commission now become required command to the all of Christian people. It feels like "dry" when some Christian people not doing the Great Commission in his/her life. Jesus mandate on this one is become more special when churches is labeling "Great" on that Commission. Maybe is forgotten by many people, but content from Great Commission is not only about three command, is one more command, that is: teaching them to obey everything I have commanded you. The word "teaching" in this command give some "didactic" smell in Great Commission. This thing interest researchers to know about didactic dimension in Great Commission of Jesus Christ. Qualitative method with descriptive approach is choose to use in this research. Data will collecting by library research method with hermeneutic technic.
\end{abstract}

Keywords: The Great Teacher, Didactic, Commission.

\section{Introduction}

It is undeniable that a large number of people in Christian groups put the "great commission" in a special position. There are many people from several Christian groups who believe that the great commission is a special command from Jesus that the mandatory dimension is far deeper than other commands, even deeper than the command to love (the first law). This understanding more or less affects the perspective of Christians in living religious life, especially in fostering relationships with other religions. This is important because during the great commission many times are understood "raw" without experiencing the process of "cooking" first (not through the hermeneutic process. If analogous, then so far there have been a large number of Christians who consume "raw food" in terms of having logic in the church and socializing in the community.

The great commission is recorded in the Gospel of Matthew 28: 16-20, but there is also a similar command in the Gospel of Mark 16:15 which is written like this: "... preach the gospel to all creatures". The most striking command at the same time that dominates the great commission is the command to "evangelize" or preach the gospel. Radical Christian groups still assume that the order is to convert all people (Christianization). If this is indeed true, then is the primary mission of a follower of Jesus to convert everyone? If investigated further, it seems that all the holy books of all religions have the potential to be understood radically. What happens if all religions understand the scriptures radically and execute their scriptural commands by "appealing" and "indoctrinating" followers of other religions and making them adherents of the same religion? Honest confession is needed to answer this question, ie the 
most likely thing to happen is "war". This is indeed very futuristic and sounds like a prediction of the future. But if this really is going to happen, then is the purpose of the great commission to divide and create war? It seems impossible if God has such a cruel purpose. Therefore, it is highly probable that it is humans who actually misunderstand this command. In the context of Christianity, it is the people who have been reading the correct text with the "wrong eye".

\section{Theoritical Framework}

Exegesis of Matthew Text 28: 16-20. Although it is very thick with the spices of the preaching of the gospel, the great commission of Matthew's version (which has been widely known rather than the Mark's version) turns out to be composed of four orders [1]. The commandments are: go, make disciples of all nations, baptize and teach. Therefore, to discuss and interpret this part of the great commission, it will be discussed based on the four commandments [2].

\subsection{Having Gone}

This command is the opening command in the great commission. "Go/Having Gone" here is translated from the wordporeuqe,ntej"Poreuthentes" which literally means "to go, travel, adventure, travel and move. In essence, this commandment was addressed to the students (eleven apostles at the time) to not only be static and stay still, but to travel and do adventures. The purpose of this command is most likely for students to go outside the Galilee region and even out of the Asia Minor region and migrate to other regions. Thus, this section actually contains an order to leave the comfort zone [3].

\subsection{Make All Nations My Disciples}

Make all the disciples of Jesus the second commandment that appears in the great commission. This one command is a follow-up to the first commandment. In other words, after students are told to leave, this is not a directionless departure. The main purpose of the disciples' "departure" or "departure" was to make disciples of all nations Jesus. All nations in this context seem to refer to all people because they are translated into Greek wordse;qnh"ethne" from the basic worde;qnoj (nation or person). However, because this noun appears in a plural number, the direction is no longer all nations but Gentile nations or at that time called Gentiles. Through this command it is clear that the disciples were sent to make Gentile (non-Jewish) nations disciples of Jesus. If the research stops here, then the conclusion that can be drawn is that this great commission is indeed a command for the spread of Christianity. But apparently the research is not over yet and there are still many things to consider. If there are people or Christian leaders who draw the conclusion that the essence of Christianity is a mission for Christianity, it is probable that their research has stopped here. But apparently Jesus' command was to make them disciples and not "adherents" of religion. It is also worth remembering that at that time Jesus did not bring religion and his mission was Misio Dei, not the mission of Christianization. The emergence of Christian terms and names is found in Acts 11:26 [4]. When the disciples gather at Antioch, where the events of Jesus ascended to heaven are long enough to pass [5].

The important thing here is about the word "student". The equivalent word that fits this word is "teacher". Because if there are students, then there is definitely someone who becomes 
the teacher. These two terms are certainly very close to schools as formal educational institutions. Within the scope of the campus may be better known by lecturers and students. It is interesting that the relationships that are built in the book of Matthew are teachers and students, not religious leaders and adherents of religion. Apparently, this impression is what Jesus wanted to build. The dimension to be revealed in this command is not evangelism in the frame of Christianization, but an intellectual intention of the Great Teacher. From this, the didactic dimension of the great commission of Jesus Christ is clearly seen. Because students are not followers of the teacher's religion, but rather people who follow the teacher's education and behavior. In schools today, there are many teachers whose religion is different from his students, but when education is carried out properly and sincerely, then religious differences are not able to hinder it. This one command was Jesus 'command to the disciples so that they could make all the nations of Jesus' disciples and inadvertently imply the mission of educating the nations on the shoulders of the disciples [6].

\subsection{Baptize}

Baptism is a sacrament in Christianity. This is one example of Jesus that He lived and He received and He set an example for every believer. During this time the word baptism is always associated with the rite, namely the act of splashing, washing or drowning people in water as a sign he entered the kingdom of God. By church dogma, baptism is considered a sign and a stamp of joining a person as a citizen of God's kingdom. Because of this understanding, the command "baptism" in the arrangement of the great commission is considered as a command to convert all people by baptizing them. In fact, very few people want to return to substantial baptism based on the biblical message. The word baptism is translated from Greekbapti, zontej (Baptizontes) from basic word bapti, zw (Baptizo) which translates drowned or baptized [7]. But the basic meaning of this word is not about the rite (baptism), but the meaning behind the activity. Baptizing involves water which is a symbol of "beginning" orò $\rho \chi \eta$ (arkhe) which translates "beginning or beginning". The Semites and Greeks believe that the beginning of all life is water. Water, which is one of the most important elements in baptism, also symbolizes the same meaning, which is life. This water symbol also indicates that before baptism is received by a person, he has not received life (death). Therefore the original meaning of baptism which is a symbolic act is to experience the death of the old life (leave the old life) and accept life through resurrection with Jesus Christ. When "rising from the dead", then someone who has been baptized is not his old self anymore. He has become a new person whose life belongs to Christ. This is a true sign that a person has been officially sealed as a citizen of God's kingdom, because he has left behind patterns and long lives. Therefore, this one message is not to force people to Christianize through baptism, but to teach someone to "kill the old life" and rise in the new life with Jesus Christ. If so, then the target is no longer strangers (non-Christians), but also Christians. It is possible that someone has received the sacrament of baptism symbolically, but the pattern of life does not reveal any newness, still the same as the old one. Thus the meaning of baptism is not carried out in full.

\subsection{Teach Them to do}

This one command comes with a didactic element that is so strong and prominent. The last command of this great commission order records Jesus' mandate to teach them to apply and carry out whatever Jesus commanded the students (11 disciples at the time). The word "they" 
seems to refer to every believer at the time. Now the question that arises is: what did Jesus command that should be taught to believers? To know this, it is very important to summarize the journey of Jesus' ministry and make it possible to be taught. If you pay attention and try to summarize, then all of Jesus' ministry, work and teaching actually talk about "love". Therefore this commandment aims to teach believers to always apply love in their lives [8].

If you pay attention, there is not a single command that leads to Christianization in this great commission structure. All delivered by Jesus in the context of His love for humans and certainly not burdensome humans. More attention to this text will show that in fact these four commands are not separate commands but have continuity. The combination of the four commandments is to leave the comfort zone to those who do not know Jesus (then) and introduce Jesus to them. Keep in mind that there was no such thing as Christianity at the time, so the command to Christianize was impossible. After leaving and departing from the comfort zone, the disciples were instructed to make disciples of all the nations of Jesus, the purpose of which was for the nations to emulate the life of Jesus who liked to create peace. If this is truly enforced, then there will be no more war and life will always be filled with peace. After that, those who imitate Jesus' behavior and actions are "baptized" in the sense of being taught to abandon the old deeds and rise up as new persons whose lives are similar to the Master's. After all that is done, then they are equipped to spread the same thing, namely Christ's love for others. Thus, the great commission is indeed a mission, but it is not a mission to convert all people to Christianity, but rather a mission to spread the love of Christ to all people, even those who do not know Christ.

\section{Research Method}

This research is using Qualitative method with Critical Historical Approach. This method is using to collect information from the Bible and than get the data. In this cae, researcher feel so curious about what Jesus mean with His Great Commission. Critical Historical approach is selected because according to researcher eye, that approach will guide to know so much about life background in that age context so reader and researcher will understand why Jesus do that.

\section{Discussion}

Life as a religious community is indeed complicated to live. The complexity starts with determining the balance between the heavenly and the secular. Preparing for things that are heavenly is indeed something very important, but there is a fact that cannot be denied either, that there are secular things that need special attention. From this research it was found that Jesus in His great commission voiced to take education seriously. This is evident when a didactic dimension that is so strong is found in His message. Speaking of education, surely many agree that this is a discussion in the secular realm, very different from the discussion of "born again, the promise of faith, hope, rapture and so forth" that is spiritual.

The great commission ultimately teaches that life is not about distinguishing between spiritual and secular. The most important thing here is to do Jesus' command because it is realized that the command is useful for many people too. The great commission has a dimension of "educating" that is so powerful. Therefore, the campus as one of the formal 
educational institutions, so far, has unconsciously been undergoing and carrying out the great commission of Jesus Christ.

\section{Conclusion}

This era is a fairly cruel era. Without education and mastery of technology and information, what a person receives is just being left behind. In contrast to previous eras whose development has matched the development of human resources, this era or era has urged people to develop quickly because the times have developed rapidly independently. That means that education has now taken a crucial position. Because the times are moving without waiting for humans, education has shifted and become one of the basic needs (equivalent to food, clothing and shelter).

The importance of education has apparently been realized by Jesus for a long time, namely since the days of the New Testament. One proof is when the didactic dimension was found in the great commission. Jesus' command to "teach them" in the phrase "teach them to do" is indeed aimed at getting people to teach one another about acts of love. But on the other hand it was also found God's decision to involve humans in the task of "teaching" about his greatest work. The Bible testifies that God is love, so teaching about love is also teaching about God. What is important here is the task of teaching about love. From the beginning Jesus understood well that education was very important for believers. Therefore, the present generation of Christians should not only concern themselves with Christianizing all nations or merely be confined to taking care of spiritual things and turning a blind eye to the secular. In the end the church also needs to respond immediately to this very rapid development. The church also needs to maximize the mastery of technology, information and communication so that it is not obsolete and is not abandoned by the congregation. The church will lose the congregation when it is too busy preparing for heaven, but forgets to organize the world.

\section{References}

[1] Anon, Sinopsis Tiga Injil, (Jakarta: Lembaga Alkitab Indonesia, 2009), h. 232.

[2] Woodrow Kroll, Simply Jesus: Kehidupan dan Pengajaran Yesus Kristus Berdasarkan Urutan SecaraKronologi, (Yogyakarta: Andi, 2010), hh. 266-267.

[3] Geoffrey W. Bromiley, Theological Dictionary of The New Testament, (Michigan: William B. Eerdmans Publishing Company, 1985), hh. 827-828.

[4] Yoppi Margianto, Belajar Sendiri Bahasa Yunani: Berdasarkan Injil Yohanes, (Yogyakarta: Andi, 2005), hh. 32-34.

[5] K. L. McKay, A New Syntax of The Verb In New Testament Greek: An Aspectual Approach, (New York: Peter Lang, 1994), hh. 30-35.

[6] B. F. Drewes, Wilfrid Haubeck, Heinrich Von Siebenthal, Kunci Bahasa Yunani Perjanjian Baru: Kitab Injil Matius Hingga Kisah Para Rasul, (Jakarta: BPK Gunung Mulia, 2013), h. 100.

[7] Ruth Schafer, Belajar Bahasa Yunani Koine: Panduan Memahami dan Menerjemahkan Teks Perjanjian Baru, (Jakarta: BPK Gunung Mulia, 2013), h. 95.

[8] Donald K. McKim, The Westminster Dictionary of Theological Terms: Second Edition, (Kentucky: Westminster John Knox Press, 2014), hh. 666-667. 